\title{
Efektivitas Layanan Bimbingan Kelompok dalam Meningkatkan Kegiatan Merespon Pembelajaran
}

\author{
Rizky Andana Pohan \\ Institut Agama Islam Negeri (IAIN) Langsa \\ andanapohan@iainlangsa.ac.id \\ Syaiful Indra \\ Universitas Islam Negeri (UIN) Ar-raniry Banda Aceh \\ syaiful@konselor.org
}

\begin{abstract}
This study aims to determine: a description of the average condition score of activities responding to students in learning before and after treatment guidance services are given; and the effectiveness of group guidance services to improve student response activities in learning. This research uses quantitative methods. This type of research is preexperimental, using the one group pre-test post-test design. The selection of subjects in this study uses a non-random sampling technique with a purposive sampling method. The subjects of this study were ten people and were treated for six meetings. The instrument used was the Responding scale Rizky Andana Pohan Likert scale model. Data were analyzed using non-parametric statistical techniques using the Wilcoxon Signed Ranks Test with the help of SPSS version 17.00. The research findings show that in general group guidance services are effective in increasing response activities in learning, while specifically this study describes: there are differences in the average score of student response activities before and after group guidance services are provided. Based on the results of this study, it can be concluded that the activities of responding to students in learning can be improved through group guidance services.
\end{abstract}

Keywords: Effectiveness, responding activity, group guidance

\begin{abstract}
Abstrak
Penelitian ini bertujuan untuk mengetahui: gambaran kondisi rata-rata skor kegiatan merespon mahasiswa dalam pembelajaran sebelum dan setelah diberikan perlakuan layanan bimbingan; dan efektivitas layanan bimbingan kelompok meningkatkan kegiatan merespon mahasiswa
\end{abstract}


dalam pembelajaran. Penelitian ini menggunakan metode kuantitatif. Jenis penelitian ini adalah pre-eksperimen, menggunakan the one group pre-test post-test design. Pemilihan subjek dalam penelitian ini menggunakan teknik non-random sampling dengan metode purposive sampling. Subjek penelitian ini berjumlah sepuluh orang dan diberi perlakuan selama enam kali pertemuan. Instrumen yang digunakan skala Merespon Rizky Andana Pohan model skala Likert. Data dianalisis menggunakan teknik statistik non-parametrik dengan menggunakan Wilcoxon Signed Ranks Test dengan bantuan SPSS versi 17.00. Temuan penelitian memperlihatkan bahwa secara umum layanan bimbingan kelompok efektif dalam meningkatkan kegiatan merespon dalam pembelajaran, sedangkan secara khusus penelitian ini memaparkan tentang: terdapat perbedaan rata-rata skor kegiatan merespon mahasiswa sebelum dan setelah diberikan layanan bimbingan kelompok. Berdasarkan hasil penelitian ini, dapat disimpulkan bahwa kegiatan merespon mahasiswa dalam pembelajaran dapat ditingkatkan melalui layanan bimbingan kelompok.

Kata Kunci: Efektivitas, layanan bimbingan, kelompok belajar

\section{Pendahuluan}

Pada Tahun 2030 Indonesia akan menghadapi bonus demografi, dimana usia produktif akan lebih banyak jumlahnya dibandingkan dengan usia tidak produktif. ${ }^{1}$ Untuk mengantisipasi hal tersebut maka pemerintah mengeluarkan kebijakan Kerangka kualifikasi Nasional Indonesia (KKNI) yang menentukan level keahlian dalam semua jenjang pendidikan. ${ }^{2}$ Menyikapi hal tersebut Kementerian Agama melalui Direktorat Pendidikan Tinggi Islam (Diktis) telah mengeluarkan Standard Kompetensi Lulusan (SKL) dan Standard Capaian Lulusan (CPL) berdasarkan standard KKNI. ${ }^{3}$ Salah satu Program Studi (Prodi) yang ada di Perguruan Tinggi Keagamaan Islam tersebut adalah Prodi Bimbingan Konseling Islam (BKI) yang ada di Fakultas Dakwah dengan profil lulusan sebagai pembimbing, konselor Islam, dan asisten peneliti sosial keagamaan. Prodi BKI Institut Agama Islam Negeri (IAIN) Langsa langsung menyesuaikan SKL dan CPL Diktis tersebut dengan melakukan peninjauan kurikulum setiap tahunnya. ${ }^{4}$

${ }^{1}$ Brodjonegoro, B. 2017. Bonus Demografi 2030-2040: Strategi Indonesia Terkait Ketenagakerjaan dan Pendidikan. Jakarta: Bappenas.

${ }^{2}$ Permendikbud Nomor 73 Tabun 2013 tentang Penerapan KKNI Bidang Pendidikan Tinggi. Jakarta: Kemendikbud RI.

${ }^{3}$ Direktorat Pendidikan Tinggi Islam. 2018. Standar Kompetensi Lulusan (SKL) dan Capaian Pembelajaran Lulusan (CPL) Program Studi Jenjang Sarjana Pada Perguruan Tinggi Keagamaan Islam dan Fakultas Agama Islam (FAI) Pada Perguruan Tinggi. Jakarta.

${ }^{4}$ Buku Panduan Akademik IAIN Langsa Tahun 2018. Langsa, 2018. 
Salah satu mata kuliah keahlian berkarya yang wajib diikuti oleh setiap mahasiswa BKI adalah Pendekatan dan Teknik dalam Konseling ${ }^{5}$. Berdasarkan hasil observasi T.P 2017-2018 semester genap mahasiswa dari tiga kelas dengan jumlah mahasiswa 50 orang pada mata kuliah ini penilaian terhadap mahasiswa pada mata kuliah ini, $30 \%$ mahasiswa masih belum berani untuk aktif merespon dalam pembelajaran, padahal mata kuliah ini menuntut mahasiswa untuk dapat menguasai secara teori dan praktik ${ }^{6}$. Hasil ujian akhir dengan metode praktik penanganan kasus menunjukkan bahwa 20\% mahasiswa belum mampu menyelesaikan kasus dengan maksimal. Jika hal ini dibiarkan terus-menerus, maka dikhawatirkan mahasiswa BKI akan lemah dalam penguasaan kompetensi profesional konseling ${ }^{7}$.

Kegiatan merespon merujuk pada tiga kegiatan inti yaitu: menanya, menjawab, dan mengemukakan pendapat. ${ }^{8}$ Lebih dari empat puluh tahun yang lalu Carner seorang pakar pendidikan menyarankan bahwa para pendidik harus fokus memperhatikan respon peserta didik dalam pembelajaran, salah satunya adalah bertanya. ${ }^{9}$ Magnesia menyatakan bahwa keberhasilan dalam belajar terjadi dengan: membaca sebanyak 10\%, mendengar sebanyak $20 \%$, melihat $30 \%$, melihat dan mendengar 50\%, mengatakan $70 \%$, serta mengatakan dan mengerjakan sebanyak 90\%. ${ }^{10}$ Sokrates pada zaman Yunani kuno juga menggunakan teknik menanya sebagai salah satu cara yang paling dasar untuk mendapatkan pengetahuan. Alquran Surat Al-An'am Ayat 76-79 menerangkan bahwa Nabi Ibrahim mulai merekonstruksi pengetahuan mengenai proses penciptaan alam semesta dimulai dengan mengamati, menanya pada diri sendiri, sampai benar-benar menemukan Tuhan sesungguhnya yaitu Allah SWT. ${ }^{11}$ Selanjutnya, Marbach-Ad dan Sokolove menjelaskan bahwa pengetahuan yang baik dimulai dengan respon yang baik oleh peserta didik. ${ }^{12}$ Hal tersebut menjadi

5Panduan Kurikulum Berbasis KKNI Program Studi Bimbingan dan Konseling Islam IAIN Langsa. Langsa, 2017.

${ }^{6}$ Hasil Observasi Pembelajaran Pada Mata Kuliah Pendekatan Teknik dalam Konseling Prodi BKI IAIN Langsa. Februari-April 2019.

${ }^{7}$ Formulir Penilaian Ujian Akhir Semester Mahasiswa Prodi BKI Tahun 2019.

${ }^{8}$ Khoiri, N., \&Pohan, R. A. (2018). KEGIATAN MERESPON DALAM PEMBELAJARAN SERTA IMPLIKASINYA DALAM BIMBINGAN DAN KONSELING. Consilium: Berkala Kajian Konseling dan Ilmu Keagamaan, 4(4).

${ }^{9}$ Marbach-Ad, G. dan Sokolove, P. G. (2000). "Good Science Begin With Good Questions". Journal of College Science Teaching, Vol. 30, No. 3, (192-195). Hlm 192.

${ }^{10}$ Hosman, M. (2014). Pendekatan Saintifik dan Kontekstual dalam Pembelajaran Abad 21: Kunci sukses implementasi Kurikulum 2013. Jakarta: Ghalia Indonesia. hlm 207.

${ }^{11}$ Az-Zuhaili, W. (2010). Tafsir Al-Wasith: Al-fatibah - at-taubah 1. Terjemahan oleh Muhtadi, dkk. Jakarta: Gema Insani. hlm 495.

${ }^{12}$ Marbach-Ad, G. dan Sokolove, P. G. (2000). "Can Undergraduate Biology Students Learn to Ask Higher Level Questions?”. Journal of Research in Science Teaching, Vol.37, No. 8, (854870) 
sebuah tanda betapa pentingnya kegiatan merespon yang dilakukan peserta didik dalam pembelajaran.

Berdasarkan data pada Prodi BKI IAIN Langsa T.P 2017/2018 ditemukan bahwa mahasiswa masih mengalami kesulitan dalam bertanya sebanyak $60 \%$. Selanjutnya untuk menjawab pertanyaan dan mengemukakan pendapat sebanyak $70 \%$. Hal ini tentunya menjadi permasalahan nyata dalam proses perkuliahan, dengan berdampak pada nilai akhir perkuliahan mahasiswa yang belum maksimal. Selanjutnya berdasarkan data hasil penilaian pada mata kuliah pendekatan dan teknik konseling, masalah merespon masih menjadi masalah utama yang dialami mahasiswa dalam perkuliahan. Sebanyak 60\% mahasiswa yang mengambil mata kuliah ini, mengalami masalah pada aspek respon dalam perkuliahan, sehingga proses perkuliahan cenderung pasif, hal ini tentunya berdampak pada penguasaan materi dan hasil belajar yang didapatkan oleh mahasiswa. Kegiatan merespon masuk dalam kegiatan belajar peserta didik saat pembelajaran di kelas. ${ }^{13}$ Salah satu intervensi pelayanan konseling yang dapat dilakukan untuk membantu mahasiswa dalam meningkatkan responnya saat proses pembelajaran adalah layanan bimbingan kelompok.

Prayitno menjelaskan bahwa layanan bimbingan kelompok mengaktifkan dinamika kelompok untuk membahas berbagai hal yang berguna bagi pengembangan diri pribadi yang menjadi anggota kelompok. ${ }^{14} \mathrm{Pada}$ layanan bimbingan kelompok memungkinkan semua anggota kelompok untuk aktif merespon dengan prosedur dan teknis yang dilakukan. Hal ini dikarenakan dalam layanan bimbingan kelompok kesempatan mengemukakan pendapat, tanggapan, dan berbagai reaksi pun dapat merupakan peluang yang sangat berharga bagi individu. ${ }^{15}$ Dinamika kelompok akan berkembang karena suasana kelompok yang heterogen dan dipimpin oleh pemimpin kelompok yang profesional. Menyikapi kurangnya respon mahasiswa dalam proses pembelajaran yang mengakibatkan rendahnya hasil belajar mahasiswa, maka peneliti tertarik untuk meningkatkan keaktifan mahasiswa BKI dalam mata kuliah pendekatan dan teknik dalam konseling melalui layanan bimbingan kelompok. Hal ini juga berdasarkan analisis terhadap hasil penelitian Rahmi bahwa layanan bimbingan kelompok efektif untuk meningkatkan keterampilan bertanya dan menjawab mahasiswa. ${ }^{16}$

\footnotetext{
Depdiknas.

${ }^{14}$ Prayitno. (1995). Layanan Bimbingan dan Konseling Kelompok (Dasar dan Profil). Jakarta: Ghalia Indonesia.

15Praytino, dkk . (2017). Layanan Bimbingan Kelompok dan KonselingKelompok yang Berhasil. Bogor: Ghalia Indonesia.

${ }^{16}$ Rahmi, A. 2010. "Efektivitas Layanan Bimbingan Kelompok untuk Meningkatkan Keterampilan Bertanya dan Menjawab Pertanyaan Mahasiswa". Tesis tidak diterbitkan. Padang: Program Pascasarjana Universitas Negeri Padang.
}

${ }^{13}$ Prayitno dkk. (2002). Seri Latiban Keterampilan Belajar. Jakarta: Dirjen Dikti PPMPT 
Tujuan penelitian ini adalah sebagai berikut: (1) menggambarkan perbedaan kegiatan merespon dalam pembelajaran sebelum dan setelah diberikan perlakuan layanan bimbingan kelompok, (2) menguji efektivitas layanan bimbingan kelompok untuk meningkatkan kegiatan merespon dalam pembelajaran. Penelitian ini menggunakan jenis penelitianpre-eksperimen dengan The One Group Pre-test Post-test Design. Penelitian ini tidak menggunakan kelompok kontrol karena hanya memberi perlakuan pada kelompok yang mengalami masalah yaitu memiliki aktivitas merespon yang rendah. Instrumen yang digunakan adalah Skala Merespon Rizky Andana Pohan model Likert, dengan jumlah item sebanyak 16 dan memiliki 3 indikator yaitu: menanya (item $1,2,3,4,5)$ menjawab pertanyaan (item $6,7,8,9,10$ ), dan mengemukakan pendapat (item 11, 12, 13, 14, 15, 16). ${ }^{17}$ Selanjutnya nilai validitas instrumen sebesar 0.672 dan reliabilitas sebesar 0.921. Kegiatan penelitian dilakukan sebanyak delapan kali pertemuan dimulai pada Tanggal 19 Juni 2019 - 2 Agustus 2019. Pertemuan pertama dilaksnakan pre-test, enam kali pelakanaan bimbingan kelompok dengan materi: 1. Hakikat dan proses pembelajaran/perkuliahan, 2. Persepsi tentang kegiatan merespon, 3. Kepercayaan diri dalam merespon, 4. Kecerdasan emosi, 5. Motivasi berprestasi, 6. Self esteem, dan pertemuan terakhir dilaksanakan post-test. Subjek penelitian menggunakan teknik non random sampling dengan metode purposive sampling. Subjek penelitian diambil dari mahasiswa yang memiliki skor di bawah 66 atau di bawah tinggi sehingga jumlah subjek dalam penelitian ini sebanyak 10 orang mahasiswa. Data dianalisis dengan statistik non parametrik yaitu Wilcoxon Signed Ranks Test.Analisis data dibantu dengan menggunakan program SPSS versi 17.00 .

\section{Hasil dan Pembahasan}

\section{Deskripsi Data}

Kegiatan penelitian dilakukan kepada 10 (sepuluh) orang mahasiswa yang terdiri dari empat orang mahasiswa memiliki kondisi kegiatan merespon rendah, tiga orang sedang, dan tiga orang tinggi.

\section{Hasil Pre-test dan Post-test Kegiatan Merespon dalam Pembelajaran}

Tujuan dilakukannya pre-test adalah untuk mengetahui gambaran awal kondisi kegiatan merespon dalam pembelajarn sebelum diberikan perlakuan berupa layanan bimbingan kelompok. Sedangkan post-test diberikan untuk melihat perubahan kondisi kegiatan merespon dalam pembelajaran setelah

17Pohan, R. A., Daharnis., Bentri, A. 2016. "Kontribusi Kepercayaan Diri dan Persepsi Siswa Terhadap Kegiatan Merespon dalam Pembelajaran Serta Implikasinya dalam Pelayanan Bimbingan dan Konseling”. Tesis. Padang: Fakultasi Ilmu Pendidikan Universitas Negeri Padang. 
subjek penelitian memperoleh perlakuan. Data pre-test dan post-test dapat dilihat pada Tabel 1 berikut.

Tabel 1. Hasil Pre-test dan Post-test Kegiatan Merespon

dalam Pembelajaran

\begin{tabular}{lcccc}
\multirow{2}{*}{ InisialMahasiswa } & \multicolumn{2}{c}{ Pre-test } & \multicolumn{2}{c}{ Post-test } \\
\cline { 2 - 5 } & Skor & Kategori & Skor & Kategori \\
\hline AYU & 52 & Tinggi & 73 & SangatTinggi \\
\hline HER & 43 & Sedang & 67 & SangatTinggi \\
\hline CIF & 32 & Rendah & 48 & Sedang \\
\hline UMH & 54 & Tinggi & 66 & Tinggi \\
\hline MLS & 46 & Sedang & 67 & SangatTinggi \\
\hline RHM & 48 & Sedang & 73 & SangatTinggi \\
\hline IPM & 35 & Rendah & 58 & Tinggi \\
\hline IPS & 40 & Rendah & 61 & Tinggi \\
\hline DNI & 65 & Tinggi & 71 & SangatTinggi \\
\hline WDF & 35 & Rendah & 66 & Tinggi \\
\hline Skor Total & $\mathbf{4 5 0}$ & & $\mathbf{6 5 0}$ & \\
\hline Rata-rata & $\mathbf{4 5}$ & Sedang & $\mathbf{6 5}$ & Tinggi
\end{tabular}

Skor kegiatan merespon mahasiswa untuk masing-masing mahasiswa pada post-test mengalami peningkatan dari skor pre-test. Pada saat pre-test, kondisi kegiatan merespon pada umumnya sedang, kemudian setelah diberikan perlakuan dan dilakukan post-test terlihat semua skor meningkat. Kondisi kegiatan merespon yang rendah setelah diberikan perlakuan dialami oleh CIF, dan yang terbaik dialami oleh AYU. Peningkatan skor terbanyak dialami oleh WDF dan yang paling sedikit dialami oleh DNI, namun secara keseluruhan semua subjek penelitian mengalami peningkatan skor.

\section{Perbedaan Hasil Pre-test dan Post-test Kondisi Kegiatan Merespon dalam Pembelajaran}

Perbedaan frekuensi kondisi kegiatan merespon dalam pembelajaran mata kuliah pendekatan dan teknik dalam konseling untuk masing-masing kategori dari hasil pre-test dan post-test.

Tabel 2. Distribusi Frekuensi Skor Pre-test dan Post-test Kegiatan Merespon dalam Pembelajaran

\begin{tabular}{clcccc}
\multirow{2}{*}{ Skor } & Kategori & \multicolumn{2}{c}{ Pre-test } & \multicolumn{2}{c}{ Post-test } \\
\cline { 3 - 6 } & & F & $\mathbf{0}$ & F & \% \\
\hline$\geq 67$ & Sangat Tinggi & 0 & 0 & 5 & 50 \\
\hline $54-66$ & Tinggi & 3 & 30 & 4 & 40 \\
\hline $41-53$ & Sedang & 3 & 30 & 1 & 10 \\
\hline $28-40$ & Rendah & 4 & 40 & 0 & 0
\end{tabular}




\begin{tabular}{cccccc}
$\leq 27$ & Sangat Rendah & 0 & 0 & 0 & 0 \\
\hline Jumlah & & 10 & 100 & 10 & 100
\end{tabular}

Tabel 2 di atas, memperlihatkan perbedaan kegiatan merespon pada subjek penelitian antara sebelum dan sesudah mendapatkan perlakuan layanan bimbingan kelompok. Selanjutnya perbedaan kegiatan merespon mahasiswa dalam pembelajaran dapat pula dilihat dari hasil pengolahan data pre-test dan post-test melalui SPSS 17.00 sebagai berikut.

Tabel 3. Gambaran Perbedaan Pre-test dan Post-test Kegiatan Merespon dalam Pembelajaran

\begin{tabular}{lccccccc}
\multicolumn{7}{c}{ Statistik Deskriptif } \\
\hline N & \multicolumn{2}{l}{$\begin{array}{l}\text { Minimu } \\
\text { m }\end{array}$} & $\begin{array}{l}\text { Maximu } \\
\text { m }\end{array}$ & Sum & Mean & $\begin{array}{l}\text { Std. } \\
\text { Deviation }\end{array}$ \\
\hline Pre_test & 10 & 32 & 65 & 450 & 45 & 10.2 \\
\hline Post_test & 10 & 48 & 73 & 650 & 65 & 7.6
\end{tabular}

Tabel 1, 2 dan 3di atas, memperlihatkan bahwa 10 (sepuluh) subjek penelitian yang dilibatkan dalam perhitungan, mengalami peningkatan skor dari pre-test ke post-test atau mengalami peningkatan kegiatan merespon setelah diberikan perlakuan layanan bimbingan kelompok. Untuk melihat kondisi kegiatan merespon pada masing-masing mahasiswa dari hasil pre-test dan post-test dapat dilihat pada Gambar 1 berikut.

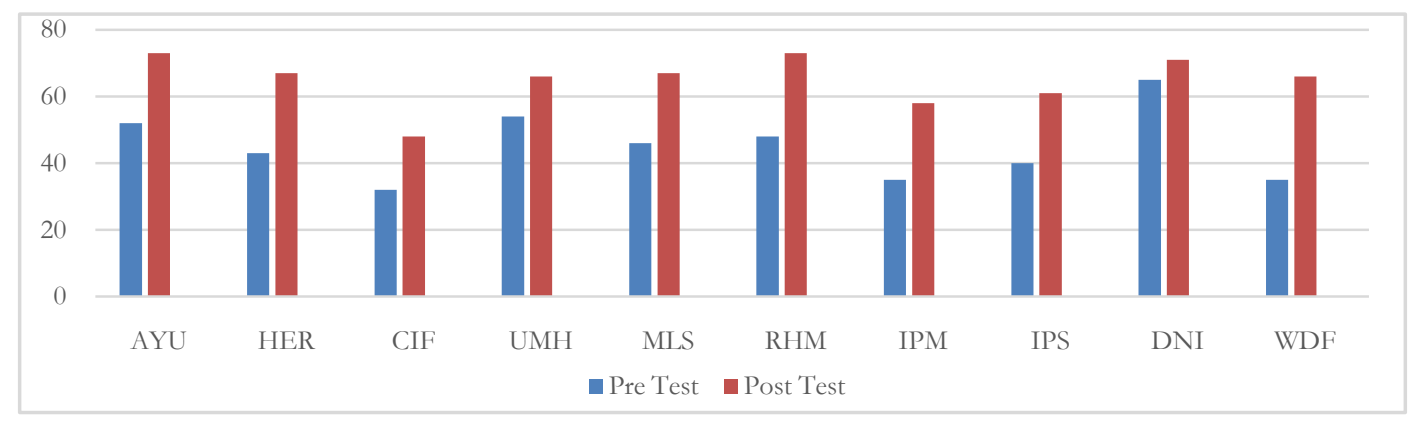

Gambar 1. Hasil Pre-test dan Post-test Kegiatan Merespon dalam Pembelajaran

Gambar 1 di atas dapat dipahami bahwa terdapat perbedaan kegiatan merespon mahasiswa sebelum dan sesudah diberikan perlakuan. Dari 10 (sepuluh) orang mahasiswa yang mendapat perlakuan, semua mahasiswa mengalami peningkatan kegiatan merespon.

\section{Pengujian Hipotesis}

Pengujian hipotesis dilakukan dengan menganalisis hasil uji Wilcoxon's terhadap data pre-test dan post-test. Hasil uji tersebut dapat dilihat pada Tabel 4 berikut. 


\section{Tabel 4. Hasil Uji Wilcoxon Signed Ranks Test Pre-test dan Post-test Kegiatan Merespon dalam Pembelajaran \\ Test Statistics ${ }^{\mathrm{a}}$

\begin{tabular}{lrr}
\hline \multicolumn{2}{c}{ Pre-test - Post-test } \\
\hline$Z$ & $-2.810^{2}$ \\
\hline Asymp. Sig. (2-tailed) & .005
\end{tabular}

Tabel 4 di atas terlihat bahwa angka probabilitas Asymp. Sig.(2tailed)kegiatan merespon subjek penelitian saat sebelum dan sesudah diberikan perlakuan sebesar 0.005, dengan demikian Ha diterima karena (Asym.Sig) < alpha yaitu $0.005<0.05$. Sehingga layanan bimbingan kelompok terbukti efektif untuk meningkatkan kegiatan merespon pembelajaran mahasiswa.

Hasil penelitian ini menggambarkan bahwa terdapat perbedaan yang signifikan antara kondisi kegiatan merespon mahasiswa dalam pembelajaran pada mata kuliah pendekatan dan teknik konseling sebelum dan setelah diberikan perlakuan berupa layanan bimbingan kelompok. Hasil pre-test memperlihatkan bahwa rata-rata mahasiswa masih berada pada aktivitas sedang saat merespon dalam perkuliahan, hal ini terlihat dengan rata-rata skor pre-test sebesar 45 yang berada pada kategori sedang sebelum diberikan perlakuan. Setelah diberikan perlakuan terlihat perubahan pada diri mahasiswa yang akhirnya sudah mulai mampu merespon dengan baik dalam perkuliahan, hal ini terlihat dengan rata-rata skor post-test sebesar 65 yang berada pada kategori tinggi. $\mathrm{Hal}$ ini berarti mahasiswa berhasil meningkatkan kegiatan dalam pembelajaran dengan dibantu mengubah persepsi dan tindakan melalui materi yang didiskusikan pada kegiatan kelompok. Hasil penelitian ini juga sesuai dengan penelitian Rizkiana bahwa layanan bimbingan kelompok efektif dilakukan untuk meningkatkan keaktifan siswa. ${ }^{18}$ Hasil penelitian ini juga senada dengan hasil penelitian Rahmi yang menunjukkan bahwa terdapat perbedaan yang signifikan antara keterampilan bertanya dan menjawab mahasiswa sebelum dan setelah diberikan perlakuan bimbingan kelompok. ${ }^{19}$

Pre-test yang telah diberikan pada responden memperlihatkan bahwa pada umumnya mahasiswa masih belum maksimal dalam memberikan respon saat perkuliahan. Mahasiswa masih merasa bahwa respon belum penting, takut salah jika memberikan respon, disamping itu usaha dan persiapan diri mahasiswa dalam mempersiapkan diri dalam perkuliahan juga merupakan salah satu faktor

\section{Rizkina,}

M.(2013). UpayaMeningkatkanKeaktifanSiswaDalamDiskusiKelompokMelaluiLayanan BimbinganKelompokPada siswakelas VIIIE di SMPN I9 Semarang (Doctoral dissertation, UniversitasNegeri Semarang).

${ }^{19}$ Rahmi, A. 2010. "Efektivitas Layanan Bimbingan Kelompok untuk Meningkatkan Keterampilan Bertanya dan Menjawab Pertanyaan Mahasiswa”. Tesis tidak diterbitkan. Padang: Program Pascasarjana Universitas Negeri Padang. 
dominan yang membuat mahasiswa mau dan tidak untuk merespon. Peningkatan kegiatan merespon mahasiswa sebelum dan setelah diberikan layanan bimbingan kelompok dapat dikarenakan oleh materi layanan/topik yang dibahas telah dianalisis sebelumnya oleh peneliti yang sesuai dengan kebutuhan mahasiswa sebagai peserta layanan. Hal ini juga tentunya berdasarkan analisis dari beberapa hadil riset terbaru mengenai faktor-faktor yang mempengaruhi kegiatan merespon dalam pembelajaran. Diantaranya hasil riset tersebut adalah persepsi, ${ }^{20}$ kepercayaan diri, self esteem dan self control $^{21}$ kecerdasan emosi, ${ }^{22}$ motivasi berprestasi dan konsep diri. ${ }^{23}$ Sehingga materi berdasarkan analisis kebutuhan dan riset tersebut juga menjadi salah satu faktor yang membuat mahasiswa merasa aktif dan sesuai dengan keadaan diri mereka, sehingga ratarata kegiatan merespon mahasiswa menjadi meningkat antara sebelum dan sesudah diberikan layanan bimbingan kelompok.

Selanjutnya aktivitas kelompok yang aktif dan dinamis juga membuat anggota kelompok secara terbuka dan sukarela mampu memberikan pendapat dan mempraktekkan penugasan yang terjadi dalam layanan bimbingan kelompok. Suasana keakraban juga terlihat dalam kelompok dengan intensitas enam kali pertemuan selama satu-dua jam setiap pertemuan, membuat mahasiswa tidak canggung lagi untuk berbicara dan merespon, meskipun sebelumnya belum akrab dan mengenal lebih dalam satu sama lain. Hal ini dikarenakan layanan bimbingan kelompok mampu meningkatkan komunikasi antar individu dalam dinamika kelompok. ${ }^{24}$ Selanjutnya keterampilan dan sikap serta peranan pemimpin kelompok menjadi hal yang sangat menentukan keberhasilan layanan bimbingan kelompok yang diberika. Pada penelitian ini yang menjadi pemimpin kelompok adalah peneliti sendiri, hal ini menjadi salah satu kelebihan dalam membahas topik dengan luas dan mendalam, sehingga

${ }^{20}$ Pohan, R. A. (2016). Kontribusi Kepercayaan Diri Dan Persepsi Siswa Terhadap Kegiatan Merespon Dalam Pembelajaran Serta Implikasinya Dalam Bimbingan Dan Konseling. Jurnal Penelitian Bimbingan dan Konseling, 1(2).

${ }^{21}$ Pohan, R. A., Sahputra, D., \& Zahra, M. T. (2018, April). Kontribusi Kecerdasan Emosi Terhadap Kegiatan Merespon Dalam Pembelajaran. In Prosiding Seminar Nasional Hasil Penelitian (Vol. 1, No. 1, pp. 298-306).

22 Pohan, R. A., Hayati, R. H., \& Sahputra, D. S. (2018). Kontribusi Motivasi Berprestasi dan Konsep Diri Terhadap Kegiatan Merespon Dalam Pembelajaran Serta Implikasinya Dalam Bimbingan dan Konseling. Wahana Didaktika, 16(2), 145-161.

${ }^{23}$ Kurniawan,

(2019). PengarubKepercayaanDiriTerhadapKegiatanSiswaDalamMerespoPembelajaranPadaSiswaK elas VIII MTs Negeri 3 Medan TabunPembelajaran 2018/2019 (Doctoral dissertation).

${ }^{24}$ Matondang, Anas Munandar, and Nora Sartika. 2018. "PELAKSANAAN LAYANAN BIMBINGAN KELOMPOK MELALUI PENDEKATAN TEKNIK BERMAIN PERAN DALAM MENINGKATKAN KOMUNIKASI NAPOSO NAULI BULUNG". ENLIGHTEN: Jurnal Bimbingan Konseling Islam 1 (1), 41-58. https://doi.org/10.32505/enlighten.v1i1.515. 
setiap anggota kelompok dapat langsung dipantau oleh peneliti sebagai dosen pengampu mata kuliah pendekatan teknik konseling tersebut.

Dinamika kelompok dalam layanan bimbingan kelompok juga membuat setiap anggota kelompok memiliki rasa saling memiliki dan menumbuhkan kekeluargaan, hal ini juga tercermin dari suasana permainan-permainan yang dilakukan mampu meningkatkan kebersamaan antar anggota kelompok. Hal ini mengindikasikan bahwa tujuan layanan bimbingan kelompok dalam penelitian ini sudah tercapai dengan baik, ini senada dengan pendapat Prayitno yang menyatakan beberapa tujuan bimbingan kelompok seperti mampu berbicara dengan orang banyak, mampu mengeluarkan pendapat, ide, saram, tanggapan, perasaan kepada orang lain, menghargai pendapat, tenggang rasa, dan menumbuhkan keakraban satu sama lain. ${ }^{25}$ Secara bertahap dalam perlakuan proses layanan bimbingan kelompok, mahasiswa juga terlihat jauh lebih aktif memberikan tanggapan dan terlibat dalam dinamika kelompok. Hal ini menandakan bahwa kecemasan-kecemasan awal yang di dalam diri secara perlahan mulai berkurang dan hilang seiring berlangsungnya beberapa pertemuan sesuai dengan topik yang dibahas. Hal ini juga senada dengan hasil penelitian Zarei, dkk yang menyimpulkan bahwa layanan konseling kelompok efektif untuk mengurangi kecemasan mahasiswa. ${ }^{26}$

Hasil penelitian ini juga mengindikasikan bahwa mahasiswa dalam proses pembelajaran, selalu ada keinginan untuk melakukan respon-respon baik verbal maupun secara non verbal, namun dikarenakan faktor-faktor dari dalam dan luar diri sehingga respon menjadi gagal. Melalui layanan bimbingan kelompok mahasiswa menjadi terlatih untuk mempersiapkan diri dan materi perkuliahan sehingga ada bahan untuk merespon, selanjutnya mahasiswa mampu beradaptasi dengan suasana pembelajaran, sehingga mampu merespon secara berkualitas dengan intensitas yang baik. Respon-respon yang baik dan berkualitas yang dihasilkan oleh mahasiswa secara langsung akan menimbulkan daya kritisnya yang tinggi, sehingga rasa keingintahuan mahasiswa semakin baik, mendorong untuk belajar lebih giat lagi terutama dalam penguasaan materi kuliah pada mata kuliah pendekatan teknik konseling yang tidak hanya menuntut mahasiswa untuk menguasai secara teori tetapi lebih jauh dapat menerapkannya dalam pelayanan konseling secara profesional. Hasil penelitian ini juga perlu ditindaklanjuti dengan penelitian lanjutan, karena masih terdapat kelemahan dan keterbatasan dalam penelitian ini, penelitian lanjutan diharapakan menggunakan

\footnotetext{
25Prayitno. (1995). Layanan Bimbingan dan Konseling Kelompok (Dasar dan Profil). Jakarta: Ghalia Indonesia. hlm 178.

26ZZarei, E., Fini, A. A. S., \&khajehzadehFini, H. (2010). A comparison of effect of group counselling methods, behavioural, cognitive and cognitive-behavioural to reduce students test anxiety in the University of Hormozgan. Procedia-Social and Behavioral Sciences, 5, 2256-2261.
} 
Rizky Andana Pohan dan Syaiful Bahri : Efektifitas Layanan Bimbingan ... | 27

kelompok kontrol serta dikombinasikan dengan pendekatan dan teknik konseling lainnya.

\section{Penutup}

Berdasarkan hasil penelitian yang diperoleh, setelah dilakukan analisis statistik, uji hipotesis dan pembahasan, maka hasil penelitian ini dapat disimpulkan bahwa terdapat perbedaan yang signifikan skor rata-rata kegiatan merespon mahasiswa kelompok eksperimen sebelum (pre-test) dan setelah (posttest) diberikan perlakuan bimbingan kelompok, dimana skor rata-rata post-test lebih tinggi dibandingkan skor rata-rata pre-test. Melalui bimbingan kelompok yang dilakukan, mahasiswa mampu memahami serta mengimplementasikan apa yang didapatkan dari kegiatan tersebut yang berkaitan dengan kepercayaan diri, persepsi tentang kegiatan merespon, motivasi berprestasi, self esteem dan konsep diri yang berpengaruh langsung pada kegiatan merespon dalam pembelajaran.

Beberapa saran yang dapat diajukan sebagai implikasi hasil penelitian ini antara lain, kepada: Mahasiswa disarankan setelah mengikuti bimbingan kelompok untuk tetap berusaha mempersiapkan diri dalam perkuliahan sehingga aktivitas merespon yang dilakukan lebih tinggi intensitasnya, maupun kualitas respon yang diberikan semakin baik. Dosen Pengampu Mata Kuliah disarankan untuk dapat memperhatikan dan menilai mahasiswa secara komprehensif terutama yang berkaitan dengan respon mahasiswa dalam perkuliahan. Konselor Unit Pelayanan Bimbingan dan Konseling Universitas disarankan untuk dapat membuat program layanan bimbingan kelompok untuk meningkatkan kegiatan merespon mahasiswa. Ketua Program Studi disarankan memprogramkan pelatihan bimbingan kelompok untuk meningkatkan kegiatan merespon mahasiswa. Pimpinan Perguruan Tinggi disarankan untuk membentuk dan mengaktifkan unit pelayanan bimbingan dan konseling universitas untuk membantu mahasiswa dalam mengembangkan KES dan mengentaskan KES-T terutama terkait dengan peningkatan kegiatan merespon. (6) Peneliti selanjutnya hendaknya bisa melakukan penelitian jangka panjang untuk melihat perkembangan kondisi kegiatan merespon mahaiswa dengan menggunakan kelompok kontrol agar bisa melihat pengaruh dan kefektifan dari perlakuan yang diberikan. 


\section{Bibliografi}

Az-Zuhaili, W. (2010). Tafsir Al-Wasith: Al-fatibah - at-taubah 1. Terjemahan oleh Muhtadi, dkk. Jakarta: Gema Insani.

Brodjonegoro, B. 2017. Bonus Demografi 2030-2040: Strategi Indonesia Terkait Ketenagakerjaan dan Pendidikan. Jakarta: Bappenas.

Direktorat Pendidikan Tinggi Islam. 2018. Standar Kompetensi Lulusan (SKL) dan Capaian Pembelajaran Lulusan (CPL) Program Studi Jenjang Sarjana Pada Perguruan Tinggi Keagamaan Islam dan Fakultas Agama Islam (FAI) Pada Perguruan Tinggi. Jakarta.

Hosman, M. (2014). Pendekatan Saintifik dan Kontekstual dalam Pembelajaran Abad 21: Kunci sukes implementasi Kurikulum 2013. Jakarta: Ghalia Indonesia.

Khoiri, N., \& Pohan, R. A. (2018). KEGIATAN MERESPON DALAM PEMBELAJARAN SERTA IMPLIKASINYA DALAM BIMBINGAN DAN KONSELING. Consilium: Berkala Kajian Konseling dan Ilmu Keagamaan, 4(4).

Kurniawan, A. (2019). Pengaruh Kepercayaan Diri Terhadap Kegiatan Siswa Dalam Merespon Pembelajaran Pada Siswa Kelas VIII MTs Negeri 3 Medan Tahun Pembelajaran 2018/2019 (Doctoral dissertation).

Marbach-Ad, G. dan Sokolove, P. G. (2000). "Can Undergraduate Biology Students Learn to Ask Higher Level Questions?". Journal of Research in Science Teaching, (Online), Vol.37, No. 8, (854-870)

Marbach-Ad, G. dan Sokolove, P. G. (2000). "Good Science Begin With Good Questions". Journal of College Science Teaching, (Online), Vol. 30, No. 3, (192195).

Matondang, Anas Munandar, and Nora Sartika. 2018. "PELAKSANAAN LAYANAN BIMBINGAN KELOMPOK MELALUI PENDEKATAN TEKNIK BERMAIN PERAN DALAM MENINGKATKAN KOMUNIKASI NAPOSO NAULI BULUNG”. ENLIGHTEN: Jurnal Bimbingan Konseling Islam 1 41-58. https://doi.org/10.32505/enlighten.v111.515.

Permendikbud Nomor 73 Tabun 2013 tentang Penerapan KKNI Bidang Pendidikan Tinggi. Jakarta: Kemendikbud RI.

Pohan, R. A., Daharnis., Bentri, A. (2016). "Kontribusi Kepercayaan Diri dan Persepsi Siswa Terhadap Kegiatan Merespon dalam Pembelajaran Serta Implikasinya dalam Pelayanan Bimbingan dan Konseling". Tesis. Padang: Fakultasi Ilmu Pendidikan Universitas Negeri Padang. 
Rizky Andana Pohan dan Syaiful Bahri : Efektifitas Layanan Bimbingan ... | 29

Pohan, R. A. (2016). Kontribusi Kepercayaan Diri Dan Persepsi Siswa Terhadap Kegiatan Merespon Dalam Pembelajaran Serta Implikasinya Dalam Bimbingan Dan Konseling. Jurnal Penelitian Bimbingan dan Konseling, 1(2).

Pohan, R. A., Sahputra, D., \& Zahra, M. T. (2018, April). Kontribusi Kecerdasan Emosi Terhadap Kegiatan Merespon Dalam Pembelajaran. In Prosiding Seminar Nasional Hasil Penelitian (Vol. 1, No. 1, pp. 298-306).

Pohan, R. A., Hayati, R. H., \& Sahputra, D. S. (2018). Kontribusi Motivasi Berprestasi dan Konsep Diri Terhadap Kegiatan Merespon Dalam Pembelajaran Serta Implikasinya Dalam Bimbingan dan Konseling. Wahana Didaktika, 16(2), 145-161.

Prayitno. (1995). Layanan Bimbingan dan Konseling Kelompok (Dasar dan Profil). Jakarta: Ghalia Indonesia.

Prayitno dkk. (2002). Seri Latiban Keterampilan Belajar. Jakarta: Dirjen Dikti PPMPT Depdiknas.

Praytino, dkk . (2017). Layanan Bimbingan Kelompok dan Konseling Kelompok yang Berbasil. Bogor: Ghalia Indonesia.

Rahmi, A. (2010). "Efektivitas Layanan Bimbingan Kelompok untuk Meningkatkan Keterampilan Bertanya dan Menjawab Pertanyaan Mahasiswa". Tesis tidak diterbitkan. Padang: Program Pascasarjana Universitas Negeri Padang.

Zarei, E., Fini, A. A. S., \& khajehzadeh Fini, H. (2010). A comparison of effect of group counselling methods, behavioural, cognitive and cognitivebehavioural to reduce students test anxiety in the University of Hormozgan. Procedia-Social and Behavioral Sciences, 5, 2256-2261. 
30 Islamic Counseling: Jurnal Bimbingan dan Konseling Islam, Vol. 4, No. 1, 2020 